\title{
High Al contents in quartz and hydrothermal alteration of the "Roseki" deposits in the Mitsuishi district, Southwest Japan
}

\author{
Hidetomo HONGU*, Akira YOSHIASA**, Masanori KUROSAWA***, Makio OHKAWA*, \\ Ryuji KITAGAWA* and Setsuo TAKENO**** \\ *Earth and Planetary Systems Sciences, Graduate School of Science, Hiroshima University, \\ Higashi-Hiroshima 739-8526, Japan \\ ** Department of Earth and Space Science, Graduate School of Science, Osaka University, \\ Osaka 560-0043, Japan \\ *** Institute of Geoscience, University of Tsukuba, Ibaraki 305-8571, Japan \\ **** Faculty of Environmental Studies, Hiroshima Institute of Technology, Hiroshima 731-5193, Japan
}

\begin{abstract}
Numerous pyrophyllite ("Roseki") deposits are found in Late Cretaceous volcanic rocks in Chugoku province, Southwest Japan. Judging from mineralogical characteristics, following five types of altered rocks can be distinguished: 1) silicified rock, 2) spotted Toseki, 3) illite-rich Roseki, 4) illite rock developed as a narrow zone and 5) pyrophyllite-bearing Roseki. In addition, clay veins are commonly observable in these alteration rocks. Concentration of various elements including trace elements such as $\mathrm{Li}, \mathrm{Na}, \mathrm{Mg}, \mathrm{Al}, \mathrm{K}, \mathrm{Ca}, \mathrm{Mn}, \mathrm{Fe}, \mathrm{Co}, \mathrm{Ni}, \mathrm{Cu}, \mathrm{Zn}$, $\mathrm{Rb}$ and $\mathrm{Pb}$ were measured by atomic absorption spectrophotometry. Trace elements such as ${ }^{7} \mathrm{Li},{ }^{23} \mathrm{Na},{ }^{27} \mathrm{Al},{ }^{39} \mathrm{~K},{ }^{49} \mathrm{Ti}$, ${ }^{55} \mathrm{Mn},{ }^{57} \mathrm{Fe},{ }^{69} \mathrm{Ga}$ and ${ }^{118} \mathrm{Sn}$ in quartz were measured by a laser ablation microprobe-inductively coupled plasma-mass spectrometry (LAM-ICP-MS). Authigenic quartz in small druse in silicified rocks contain a large amount of $\mathrm{Li}, \mathrm{Na}$, $\mathrm{K}, \mathrm{Fe}$ and $\mathrm{Al}$. Al and Li contents in authigenic quartz vary within $0.01-1.6 \mathrm{wt} \%$ and $33-75 \mathrm{ppm}$, respectively. The $\mathrm{Al}$ content of $1.6 \mathrm{wt} \%$ in natural quartz is the highest values hitherto recorded in previous papers. These analytical data permitted to establish geochemical characteristics of each altered rocks and the host volcanic rocks. Examining concentration of several elements in relation with aluminum content reveals several significant facts; $\mathrm{Li}$ is more concentrated in quartz than that in illite. Average content of $\mathrm{K}$ in the altered rocks is rather low compared with that of the host rhyolitic rocks. Elements such as $\mathrm{Fe}, \mathrm{Mn}, \mathrm{Na}, \mathrm{Mg}, \mathrm{Ca}$ and $\mathrm{Zn}$ are contained only in very small amount in the altered rocks. They are lower in altered rocks than those in the host rhyolitic rocks. These observations strongly suggest that main alteration processes of the district were the results of leaching and/or dissolution of the host rhyolitic rocks during the post volcanic hydrothermal activities.
\end{abstract}

\section{Introduction}

Numerous pyrophyllite ("Roseki") deposits occur in Late Cretaceous volcanic rocks distributed in Chugoku province, Southwest Japan. They are developed mainly in three areas: Mitsuishi (Okayama Prefecture), Shokozan (Hiroshima Prefecture) and Abu-Susa (Yamaguchi Prefecture). The mode of occurrence and mineralogy of these deposits were studied by many investigators up to the present (Kinosaki, 1963; 1965; Matsumoto, 1968; Katayama, 1969; Kamitani and Fujii, 1972; Kamitani, 1974). Concerning the genesis of the Roseki deposits, it has been believed that the deposits are formed by

II. Ilongu, hongu@ess.sci.osaka-u.ac.jp

A. Yoshiasa, yoshiasa@ess.sci.osaka-u.ac.jp Corresponding author

M. Kurosawa, kurosawa@arsia.geo.tsukuba.ac.jp

M. Ohkawa, makio.ohkawa@sci.hiroshima-u.ac.jp

R. Kitagawa,kitagawa@, sci.hiroshima-u.ac.jp

S. Takeno, takeno@cc.it-hiroshima.ac.jp hydrothermal activities related to the post volcanic or the intrusive rocks in the region. Kinosaki (1963) have clarified from his detailed field observations that these deposits occur in definite horizon of the Late Cretaceous volcanic rhyolitic rocks. He concluded that these ore deposits were formed by subvolcanic activities related to the host rhyolitic rocks.

We have already reported the K-Ar ages of the respective alteration stage on the samples collected mainly from the Roseki deposits in the Tsuchihashi mine, together with those of Yagi mine and Shinagawa Mitsuishi mine (Hongu et al., 2000). Tsuchihashi, Yagi and Shinagawa deposits are dated to be 73-80, 76.9-78.7 and $77.6 \mathrm{Ma}$, respectively. It is interesting to recognize that the younger rocks are richer in K-ion than the older ones. The latest stage of the alteration was confirmed in clay veins. Hydrothermal activity of the Mitsuishi district continued for almost $10 \mathrm{Ma}$ in the Late Cretaceous period. 


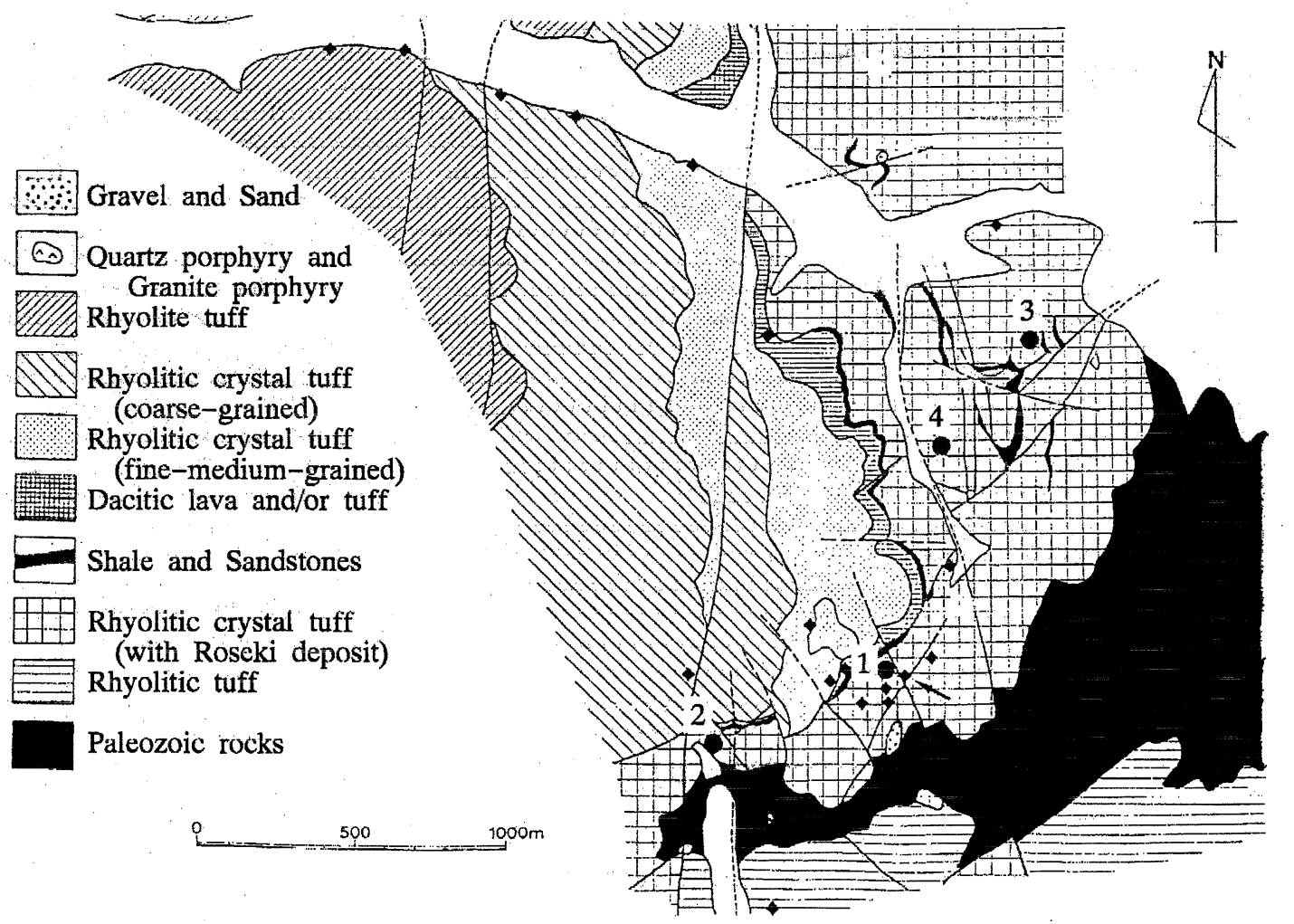

Figure 1. Geological map of the Mitsuishi district (taken from Mitsuno et al. 1984 modified by the present authors) showing localities of main "Roseki" mines $(\bullet)$ and sampling points $(\diamond)$. 1, Tsuchihashi mine; 2, Yagi mine; 3 , Shinagawa-Milsuishi mine and 4, Ohira mine.
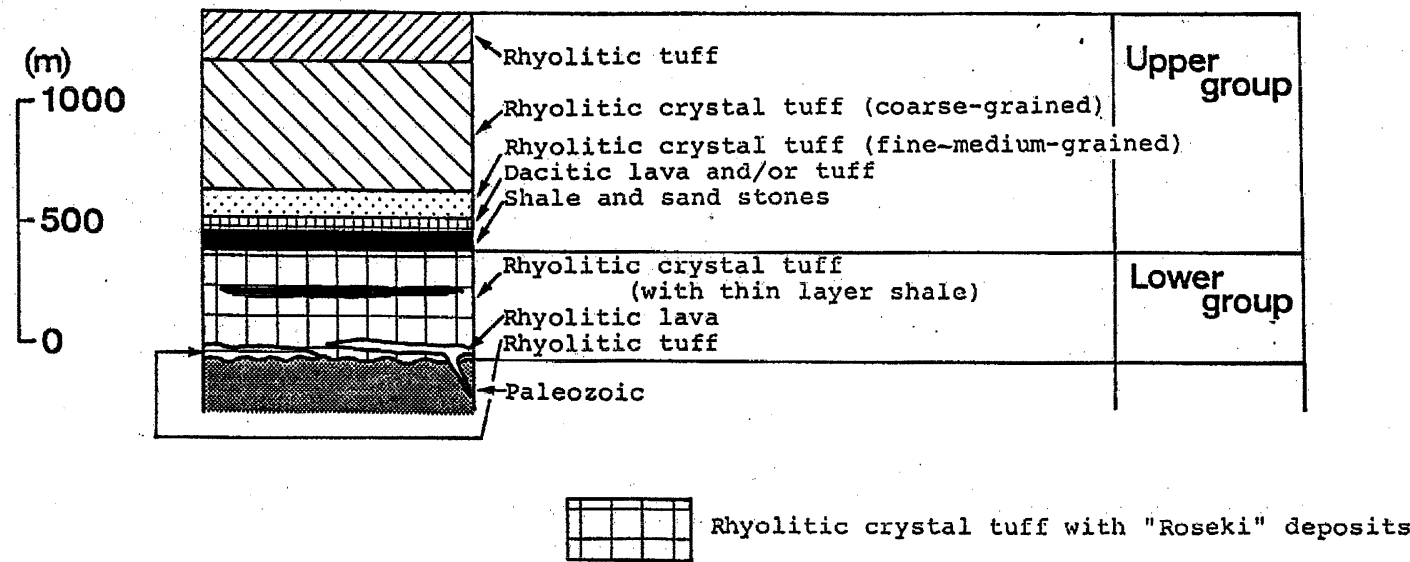

Figure 2. Volcanostratigraphy of the Mitsuishi district (after Mitsuno et al., 1984, partly modified by the present authors).

Mineralochemical studies on the Roseki deposits were carried out through the examination of constituent minerals by means of microscopical observation and X-ray diffraction method (Kamitani and Fujii, 1972; Kamitani, 1974). These Roseki deposits would be commonly associated with various alterations such as silicification, illitization and pyrophyllitization. To establish the nature of hydrothermal solution and reaction processes between the solution and the host rock, geochemical studies are indispensable as well as mineralogical studies. Some geochemical studies are published on the hydrothermal alteration of the pyrophyllite deposits (Hida et al., 1996; Terakado and Fujitani, 1998; Takagi et al., 2000). Investigation on the distribution of elements including minor and trace elements between the host rock and alteration zone associated intimately with Roseki deposits is necessary to elucidate the formation mechanism. Mutual relations 
between various alteration zones are one of the most important subjects to establish. In other word, distribution of various elements among various altered rocks in and around the "Roseki" deposits constitutes a key to trace the formation processes of the clay deposits. This paper aims to establish the nature and types of alteration in the Mitsuishi district (especially in the Tsuchihashi mine) from mineralogical and geochemical viewpoints.

\section{Outline of geology}

The basement rocks of the area are mainly composed of the Paleozoic sedimentary rocks (slate and schalstein) covered by the Late Cretaceous rhyolitic rocks (Kamitani and Fujii, 1972). The authors of the study classified the alteration zones of the host rhyolitic crystal tuff into silicified zone, the Roseki zone and the weakly illitized zone. Although they pointed out the zonal arrangement of alteration in this area, a detailed study indicates rather irregular distribution of respective zones. Figure 1 shows geological map of the district (Mitsuno et al., 1984). The Late Cretaceous rhyolitic rocks are rhyolitic crystal tuff with thin layer of shale, shale and sandstones, dacitic lava and/or tuff, rhyolitic crystal tuff (fine-medium-grained), rhyolitic crystal tuff (coarse-grained) and rhyolitic tuff in the stratigraphical ascending order. The strike of these volcanic varies gradually from NE-SW in the southern part to NW-SE in the northern part and dip is slightly westward. Roseki deposits are characteristically found in the rhyolitic crystal tuff interbeded by altered beds of thin shale and sandstone (Fig. 2). It should be noted that all of the rhyolitic crystal tuff accompanying Roseki deposits are more or less altered. The Roseki deposits are embedded in the lowest horizon of the rhyolitic rocks. The upper group is subjected almost no alteration.

\section{Sampling and experimental}

Many Roseki deposits are developed in the Mitsuishi district. Samples were collected to get as widely as possible to cover from the surrounding rhyolitic rocks, various types of altered rocks and clay vein. Sampling points are shown together with the geological map in Figure 1. The Shinagawa Mitsuishi mine in Figure 1 is situated in the Daiyama area in Bizen City, Okayama Prefecture, and the mine is famous as the oldest mine of Roseki deposit in Japan. Tsuchihashi mine is situated about $1 \mathrm{~km}$ south-southwest from the Shinagawa Mitsuishi mine. 123 specimens were collected and more than 90 percent of them were obtained from the Tsuchihashi mine. Samples were collected from every parts of the Tsuchihashi mine. In the mine, samples from various horizons were collected as shown in Figure 1. Detailed sample numbers and localities were presented in Hongu and Kohno (1990). Samples were also collected from the Yagi and Ohira mines, the former situates about $500 \mathrm{~m}$ southwest of the Tsuchihashi mine and the latter in the Daiyama area.

$\mathrm{X}$-ray powder diffraction analysis and microscopical examination were performed in order to identify the constituent minerals. Wet sieving and sedimentation method was also used for the identification.

The concentrations of various elements were determined by atomic absorption spectrophotometer (Model AA-646 atomic-absorption spectrophotometer). Measured elements are $\mathrm{Li}, \mathrm{Na}, \mathrm{Mg}, \mathrm{Al}, \mathrm{K}, \mathrm{Ca}, \mathrm{Mn}, \mathrm{Fe}$, $\mathrm{Co}, \mathrm{Ni}, \mathrm{Cu}, \mathrm{Zn}, \mathrm{Rb}$ and $\mathrm{Pb}$. Sample solutions were obtained by two types of method: (a) hydrofluorichydrochloric acids attack method and (b) alkali fusion method. About $100 \mathrm{mg}$ of sample powder were dissolved in mixed hydrofluoric and hydrochloric acids to obtain 50 or $100 \mathrm{ml}$ of sample solution was thus obtained. Since pyrophyllite-bearing samples could not be dissolved by hydrofluoric-hydrochloric acids, they were dissolved after alkali fusion. About $2 \mathrm{~g}$ of sodium carbonate and $0.3 \mathrm{~g}$ of boric acid were mixed with $100 \mathrm{mg}$ powdered samples. After fusion in platinum crucible about one hour, the melted cake was dissoled in $100 \mathrm{ml}$ of distilled water.

Compositions of quartz in silicified rocks were determined by means of a JEOL JCMA-733II electron microprobe analyzer (EPMA) and a laser ablation microprobe-inductively coupled plasma-mass spectrometry (LAM-ICP-MS). LAM-ICP-MS analyses were performed at the Venture Business Laboratory, the University of Tsukuba, using a Perkin-Elmer Sciex ELAN6000 ICP-MS instrument equipped with a laser microprobe. The ICP-MS instrument was operated at a RF power of $1050 \mathrm{~W}$, the nebulizer gas flow of 0.72 $\mathrm{L} / \mathrm{min}$, the auxiliary gas flow of $1.2 \mathrm{~L} / \mathrm{min}$, and the plasma gas flow of $15 \mathrm{~L} / \mathrm{min}$. A total of 10 isotopes in quartz such as ${ }^{7} \mathrm{Li},{ }^{23} \mathrm{Na},{ }^{27} \mathrm{Al},{ }^{29} \mathrm{Si},{ }^{39} \mathrm{~K},{ }^{49} \mathrm{Ti},{ }^{55} \mathrm{Mn},{ }^{57} \mathrm{Fe}$, ${ }^{69} \mathrm{Ga}$ and ${ }^{118} \mathrm{Sn}$ in quartz were measured with a dwell time of $10 \mathrm{~ms}$ for each element and by using a rapid peak hopping sequence in the pulse-counting mode. ${ }^{29} \mathrm{Si}$ was used as an internal standard to correct the differences in absolute amount of materials ablated and transported during analyses. The external standard was NIST SRM 612 reference material. Data reduction was performed with LAMTRACE software written by S. Jackson. A pit diameter by the laser ablation was set at 10 to $30 \mu \mathrm{m}$ in response to sample size. Details of the LAM-ICP-MS analytical conditions are presented in Kurosawa et al. (2001). 
Table 1. Classification of alteration and their main constituent minerals

\begin{tabular}{|c|c|c|}
\hline Classification & Main constituent minerals & Remarks \\
\hline Silicified rock & quartz, illite, kaolinite & Porous with pale purple color. Preserving the texture of host rock. \\
\hline Spotted Toseki & illite, quartz & $\begin{array}{l}\text { Soft illite patch with various size are commonly observed in } \\
\text { gray-white gray matrix. The color of the patch is characteristically } \\
\text { white. }\end{array}$ \\
\hline Illite-rich Roseki & illite, quartz. & $\begin{array}{l}\text { Gray to pale gray in color. Characterized by soft and smooth } \\
\text { surface preserving the texture of the host rock. }\end{array}$ \\
\hline $\begin{array}{l}\text { Illite rock developed as a } \\
\text { narrow zone }\end{array}$ & illite & $\begin{array}{l}\text { White in color. Extensively altered rock. The width of the zone is } \\
1-2 \mathrm{~m} \text {. }\end{array}$ \\
\hline Pyrophyllite-bearing Roseki & $\begin{array}{l}\text { illite, pyrophyllite, kaolinite, } \\
\text { quartz, interstratified minerals }\end{array}$ & $\begin{array}{l}\text { Developed sporadically in small size. In appearance, similar to } \\
\text { that of illite-rich Roseki. }\end{array}$ \\
\hline Clay vein & illite, quartz, kaolinite & Strike of the vein is various. Developed mainly in silicified rock. \\
\hline
\end{tabular}

\section{Results and Discussion}

\section{Mineralogy of altered rocks and clay veins}

Collected samples have been classified into the following five types of altered rocks: 1) silicified rock, 2) spotted Toseki, 3) illite-rich Roseki, 4) illite rock developed as a narrow zone and 5) pyrophyllite-bearing Roseki. In addition to the five types, clay veins are commonly developed in these altered rocks, especially in the silicified rocks. Almost all of clay veins are composed mainly of illite and quartz. Main constituent minerals and characteristics of the five types and clay vein are summarized in Table 1. Except the pyrophyllite-bearing Roseki, illite and quartz are the main constituent minerals. The silicified rock is characterized by extreme development of quartz. Using wet sieving and sedimentation method, a small amount of illite and/or kaolinite are commonly obtainable. The color of the silicified rock is usually pale purple and is characterized by porous nature. The illite rock developed as a narrow zone consists of illite alone. The pyrophyllite-bearing Roseki always contains pyrophyllite accompanying with illite, kaolinite, quartz, diaspore and interstratified minerals.

Illite patches with various sizes characterize spotted Toseki. The patch is soft and white in color. The spotted Toseki is commonly observed in the Mitsuishi area (Okayama prefecture). Difference between the illite-rich Roseki and the spotted Toseki can be recognized by relative proportion of illite to quartz, i.e. the former is more abundant in illite compared with the latter. Moreover, illite-rich Roseki is characterized by relatively soft and smooth surface on hand specimens. The illite rock developed as a narrow zone is extensively altered and developed commonly in the silicified rock. The width of the zone is about $1-2 \mathrm{~m}$. The clay vein $(<60 \mathrm{~cm})$ is developed mainly in the silicified rock. The pyrophyllite-bearing Roseki is developed sporadically in other type of alteration in relatively small size. Among these altered rocks, texture of the host rhyolitic rock is preserved in the silicified rock and illite-rich Roseki.

\section{$K$ and $A l$ contents in altered rocks and clay veins}

The distribution and partition of various elements among the five types of altered rocks and clay veins in and around the Tsuchihashi mine were investigated. Main constituent minerals are quartz, illite, kaolinite, pyrophyllite, diaspore and interstratified minerals (Table 1). Contents of $\mathrm{K}$ and $\mathrm{Al}$ can characterize these minerals. The variation of $\mathrm{K}, \mathrm{Rb}$ and $\mathrm{Li}$ contents relative to that of $\mathrm{Al}$ is shown in Figures 3, 4 and 5. Concerning $\mathrm{K}$, content against that of $\mathrm{Al}$. Linear relation is clearly recognized in Figure 3. Considering the ideal chemical composition of quartz and illite, quartz situates at the zero point and illite situates at $20.3 \mathrm{wt} \%$ in $\mathrm{Al}$ and $9.8 \mathrm{wt} \%$ in $\mathrm{K}$, and $\mathrm{K}$ content decreases with increasing the amounts of pyrophyllite and kaolinite. As is seen in Figure 3, the altered rocks of the Mitsuishi district including clay veins are characterized by silicification and illitization. Moreover, illite to quartz ratio varies from almost zero to 0.95. For example, the pyrophyllite-bearing Roseki consists of pyrophyllite, kaolinite and of some other phases. These altered rocks should fall on almost zero line of K content (refer to Fig. 10). Several points plotted apart from the line between quartz and illite (diagonal line from the zero to the upper right) because these specimens contain pyrophyllite and/or kaolinite. As is evident in Figure 3, changes of mineral assembly and migrations of elements by alteration can be represented or discussed by using such kind of diagram, i.e., plotting of concentration 
of an element vs that of Al. The diagrams representing the variation of five types of altered rocks and clay vein are closely related with the amounts of illite.

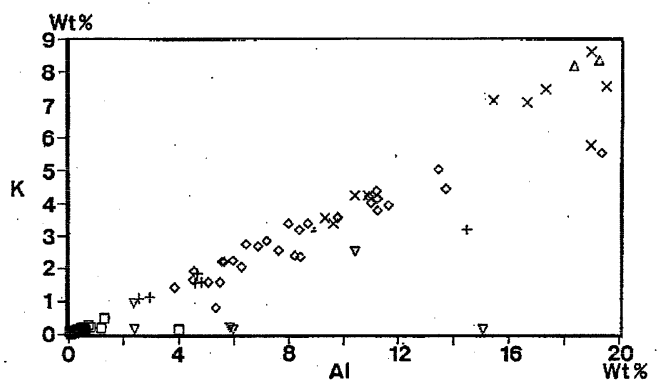

Figure 3. Variation of $\mathrm{K}$ content against $\mathrm{Al}$ content. Silicified rock ( $\square$ ), spotted Toseki(+), illite-rich Roseki $(\diamond)$, illite rock developed as a narrow zone $(\Delta)$, pyrophyllite-bearing Roseki $(\nabla)$ and clay vein $(\mathrm{x})$.

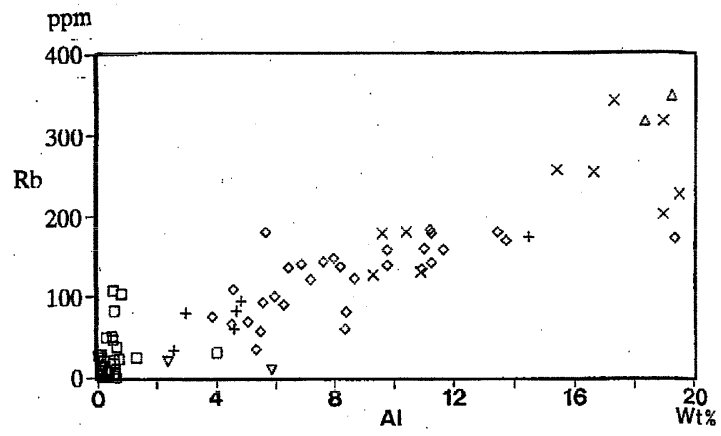

Figure 4. Variation of $\mathrm{Rb}$ content against $\mathrm{Al}$ content. Symbols are the same to those of Figure 3.

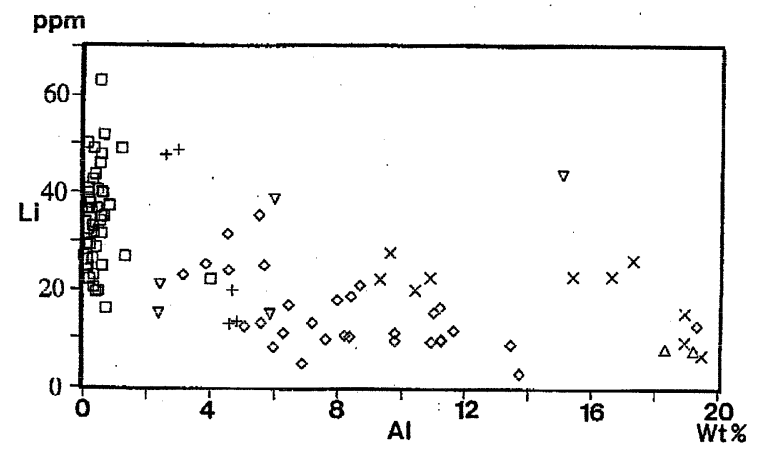

Figure 5. Variation of Li content against $\mathrm{Al}$ content. Symbols are the same to those of Figure 3.

The variation of $\mathrm{Rb}$ content as a function of $\mathrm{Al}$ content is shown in Figure 4. The distribution pattern of $\mathrm{Rb}$ is almost similar to that of $\mathrm{K}$ (Fig. 3). This observation clearly suggests the intimate geochemical relations between $\mathrm{K}$ and $\mathrm{Rb}$ as was pointed out already by Mason (1966). The result in this study indicates occupation of $\mathrm{Rb}$ ions at the K-sites in illite structure.

The variation diagram of $\mathrm{Li}-\mathrm{Al}$ is shown in Figure 5. The concentration of $\mathrm{Li}$ in the silicified rock is relatively high compared with those of other types of altered rocks. It may suggest that $\mathrm{Li}$ is contained more in quartz than illite during the formation of Roseki deposits. Li ion occupys preferentially a lattice site in quartz rather than in illite. Which site in quartz is adequate to receive $\mathrm{Li}$ is still unknown.

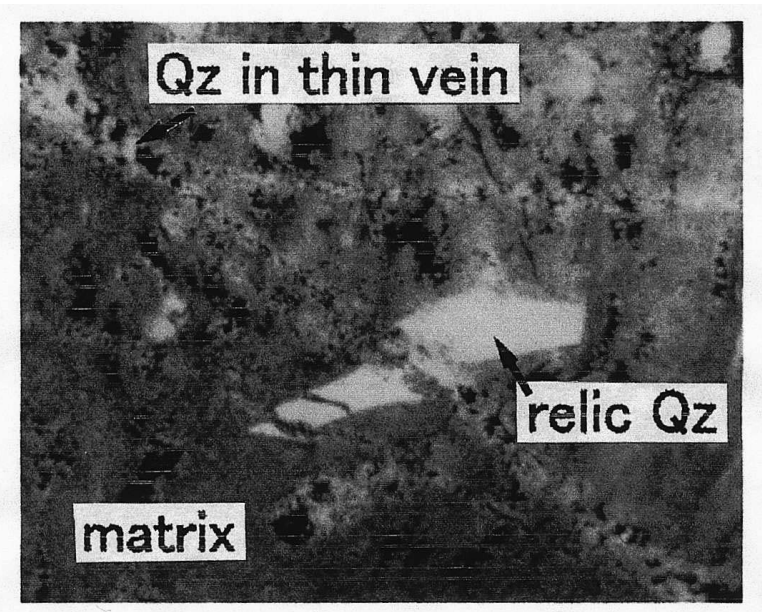

Figure 6. Photomicrograph of silicified rock from Mitsuishi Roseki deposits. Width of the photograph is $1.0 \mathrm{~mm}$. Large grained relic quartz, medium grained quartz in thin vein and fine grained quartz in matrix can be classified.

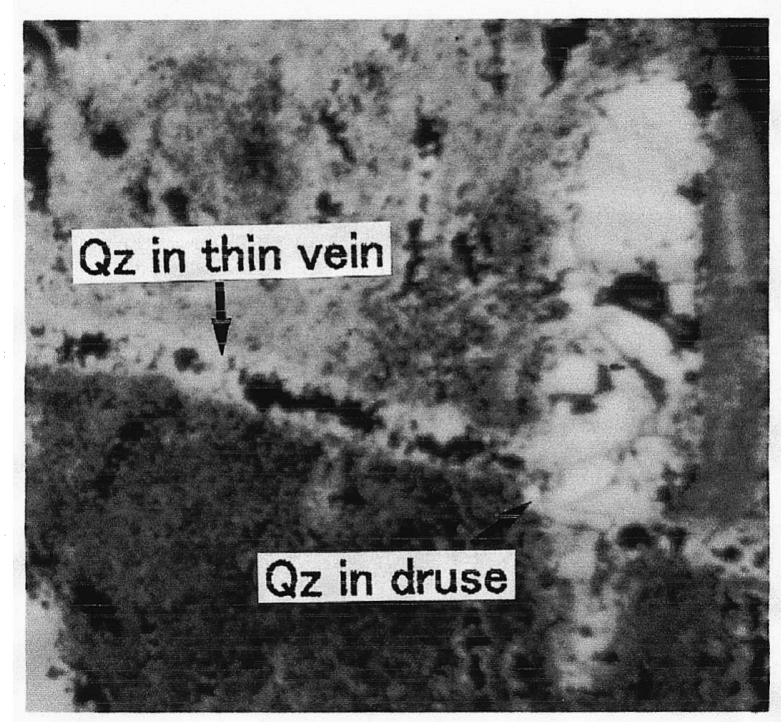

Figure 7. A typical occurrence of medium grained quartz in small druse and quartz in thin vein. Width of the photograph is $0.5 \mathrm{~mm}$.

\section{High $\mathrm{Al}$ contents in quartz from silicified rocks}

Figures 6 and 7 show the typical occurrences of quartz in the silicified rocks. Four types of occurrence on quartz can be classified by microscopical observations: 1) very fine grained quartz $(<3 \mu \mathrm{m})$ in matrix, 2) large grained 
relic quartz $(<1 \mathrm{~mm}), 3)$ medium grained quartz in thin vein $(\sim 10 \mu \mathrm{m})$ and 4$)$ medium grained authigenic quartz in small druse $(\sim 30 \mu \mathrm{m})$.

The composition of natural quartz as a whole is normally very close to $100 \% \mathrm{SiO}_{2}$ and shows low levels of trace elements relative to tridymite and cristobalite (Smith and Steele, 1984). Table 2 shows the trace element contents in quartz from silicified rocks. Using LAM-ICP-MS and EPMA, we have checked that Li is concentrated in quartz and that $\mathrm{Li}$ and $\mathrm{Al}$ contents in quartz depend largely on the type of occurrence of quartz. Large grained relic quartz has typical contents of trace elements in igneous rocks such as rhyolite (Suttner and Leininger, 1972). On the other hand, authigenic quartz in small druse and quartz in thin vein in silicified rocks have large amount of $\mathrm{Li}, \mathrm{Na}, \mathrm{K}, \mathrm{Fe}$ and $\mathrm{Al}$. The amounts of these trace elements are one or two order higher than those in Brazilian quartz (Kano and Matsui, 1987) and in quartz from igneous rocks (Suttner and Leininger, 1972).

The volume fraction of fine and medium grained quartz from the silicified rocks is greater than $95 \%$. The bulk $\mathrm{Li}$ contents measured by atomic absorption spectrophotometer ranged in concentration from 16 to 63 ppm. The bulk Li contents are same as that in medium grained quartz determined by LAM ICP-MS (Table 2). The very fine-grained quartz, as well as the medium grained quartz in thin vein and druse, seems to have comparable $\mathrm{Li}$ content. EPMA analysis revealed that $\mathrm{Al}$ contents in medium grained authigenic quartz vary in a range of $0.01-1.6 \mathrm{wt} \%$ and that of $\mathrm{Al}$ in fine grained quartz have higher than these values. It has been known that $\mathrm{Al}$ in natural quartz crystals varys from 10 to 2500 $\mathrm{ppm}$. Though the $\mathrm{Al}$ content of $1.6 \mathrm{w} \%$ in quartz from the silicified rocks is the highest among previously reported quartz (Smith and Steele, 1984; Kano and Matsui, 1987; Kano and Shinohara, 1989; Hervig and Peacock, 1989; Perny et al. 1992), the observed Al content of quartz here reported is still lower than the maximum found in synthetic quartz (Ono, 1979).

Recent studies on trace elements in quartz have shown that a part of $\mathrm{Si}$ in structure of quartz is substituted by Li together with Al (Smith and Steele, 1984; Kano and Matsui, 1987; Kano and Shinohara, 1989; Hervig and Peacock, 1989; Perny et al. 1992). Atomic proportion of $\mathrm{Al}$ in some quartz from Swiss Alps are equal to that of $\mathrm{Na}$ $+\mathrm{K}+\mathrm{Li}$ (Perny et al. 1992). Trace elements in quartz from mylonite zone show a wide range of variation in $\mathrm{Li}$ content and little variation in $\mathrm{Al}, \mathrm{Na}$ and $\mathrm{K}$ (Hervig and Peacock, 1989). Because the sum of $\mathrm{Li}, \mathrm{Na}$ and $\mathrm{K}$ in the most of quartz from the silicified rocks is less than that of $\mathrm{Al}$, a significant amount of $\mathrm{H}$ is inferred in accordance with Bambauer (1961) and Smith and Steele (1984). Kano and Matsui (1987) proposed a "coupled entrance" of $\mathrm{Li}$ and $\mathrm{Al}$ in the quartz structure and suggested that $\mathrm{Na}$ and $\mathrm{K}$ represent that in derived from fluid inclusions. Some trace elements would be derived from other small solid and/or liquid phases. It is necessary to take into account the existence of other elements such as $\mathrm{Fe}^{3+}$ and $\mathrm{Ti}^{4+}$ in Table 2. Amethyst and rose quartz contain $\mathrm{Fe}^{3+}$ and $\mathrm{Ti}^{4+}$ and both elements should substitute for $\mathrm{Si}^{4+}$ in the tetrahedral site with or without charge compensator elements situated at interstitial positions. A trivalent $\mathrm{Al}^{3+}$ ion is substituted at a $\mathrm{Si}^{4+}$ site and a monovalent cation $\mathrm{M}^{+}$such as $\mathrm{H}^{+}, \mathrm{Li}^{+}$and $\mathrm{Na}^{+}$at interstitial positions in channels parallel to the $c$-axis act as a charge compensator. The substitution gives rise to a $\left[\mathrm{AlO}_{4} / \mathrm{M}^{\prime}\right]$ center. When the charge compensated $\left[\mathrm{AlO}_{4} / \mathrm{M}^{+}\right]$center traps a hole, the cation $\mathrm{M}^{+}$diffuses away easily leading to $\left[\mathrm{AlO}_{4} / \mathrm{h}\right]$ center, where $\mathrm{h}$ is a hole trapped in a non-bonding $2 p$-orbital of oxygen located adjacent to the substitutional Al. Some Al centers should be localized around dislocations. Moreover, some important centers such as $\left[\mathrm{TiO}_{4} / \mathrm{Li}^{+}\right]$and $\left[\mathrm{H}_{4} \mathrm{O}_{4}\right]$ are also known in quartz (Ikeya, 1993). The detailed study on the existence of these elements and local structure in quartz is in progress (Yoshiasa et al., personal communication).

The variation in the trace element concentration in quartz depends on conditions such as temperature, pressure, composition and $\mathrm{pH}$ of hydrothermal solution. The content of $\mathrm{Al}$ should be high when quartz is formed at high temperature but the most probable explanation of the high $\mathrm{Al}$ content in the silicified rocks will be the peculiarity of composition and $\mathrm{pH}$ of hydrothermal solution. The variation of trace element contents in quartz depend largely on localities and can be used for the estimation of the grain origin in sands and sandstone (Masuda, 1996; Yoshiasa et al., personal communication).

\section{Variation of metallic elements contents between the alteration types and host rhyolitic rocks}

As mentioned above, rhyolitic rocks in the Mitsuishi district were divided into two types, one is almost unaltered rhyolitic rocks (upper horizon in Fig. 2) and the other altered rhyolitic rock (lower horizon) accompanied Roseki deposits. The latter rhyolitic rocks are characterized by alteration in more or less remarkable extent. Because lower and upper rhyolitic rocks belong to the same geological setting (Late Cretaceous rhyolitic rocks in the Chugoku district), it is reasonable to be assumed that the chemical compositions of both rhyolitic rocks are same. 
Table 2. Trace-element contents (ppm) in quark (grain size is larger than $30 \mu \mathrm{m}$ ) of various mode of occurrences in silicified rocks

\begin{tabular}{lccccccccc}
\hline & ${ }^{7} \mathrm{Li}$ & ${ }^{23} \mathrm{Na}$ & ${ }^{27} \mathrm{Al}$ & ${ }^{39} \mathrm{~K}$ & ${ }^{49} \mathrm{Ti}$ & ${ }^{55} \mathrm{Mn}$ & ${ }^{57} \mathrm{Fe}$ & ${ }^{69} \mathrm{Ga}$ & ${ }^{118} \mathrm{Sn}$ \\
\hline relic qz & 6 & 27 & 76 & $<8$ & 45 & $<0.5$ & $<43$ & $<0.3$ & $<0.5$ \\
& 9 & 13 & 70 & $<8$ & 47 & $<0.6$ & $<55$ & $<0.4$ & $<0.6$ \\
& 5 & 25 & 82 & $<15$ & 37 & $<1.0$ & $<71$ & $<0.7$ & $<1.1$ \\
in vein & 23 & 148 & 225 & 46 & 30 & 0.8 & 87 & 0.3 & $<1.4$ \\
in druse & 33 & 158 & 1433 & 268 & 191 & 4 & 196 & 3 & 1 \\
& 75 & 586 & 910 & 408 & 265 & 13 & 236 & 2 & 7 \\
& 59 & 265 & 1395 & 289 & 51 & 5 & 549 & 1 & 1 \\
\hline
\end{tabular}
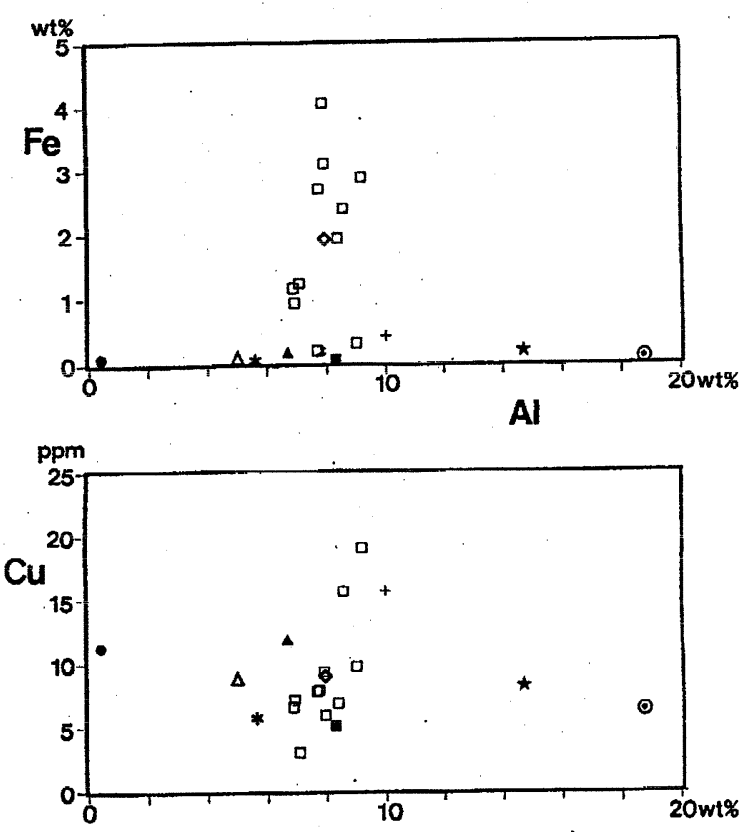

Al

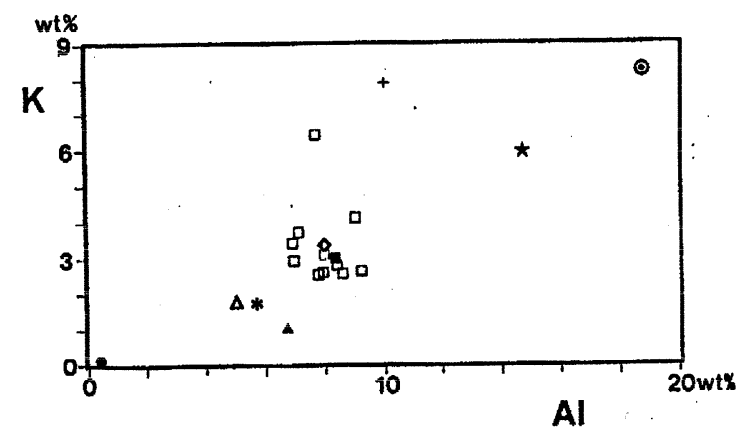

Figure 8. Variation of $\mathrm{Fe}, \mathrm{Cu}$ and $\mathrm{K}$ contents against $\mathrm{Al}$ content. Average values of host rhyolitic rocks and average values of five types of altered rocks and clay vein are represent by open lozenge $(\diamond)$ and open triangle $(\Lambda)$, respectively. Rhyolitic rocks $(\square)$, altered rocks preserving the texture of host rhyolitic rock (+). Average values of silicified rock $(\bullet)$, spotted Toseki(*), illite-rich Roseki(•), illite rock developed as a narrow zone (○), pyrophyllite-bearing $\operatorname{Roseki}(\boldsymbol{\Delta})$ and clay vein $(\star)$, respectively.

Variation of $\mathrm{K}, \mathrm{Fe}$ and $\mathrm{Cu}$ contents as a function of that of $\mathrm{Al}$ is shown in Figure 8. Average values of the two types of rhyolitic rocks (both upper unaltered and lower altered rocks) together with those of the five types of altered rocks and clay vein are also shown. Although $\mathrm{Cu}$ contents of the upper unaltered rhyolitic rocks are various, average content is almost equivalent to those of alteration rocks. That is, $\mathrm{Cu}$ contents of the alteration zone including that of clay vein should be almost similar to those of the host rhyolitic rocks. $\mathrm{Cu}$ contents are almost independent to $\mathrm{Al}$ or mineral assembly. Copper is not transported to a distant place. Here, we would conclude that the average contents of many elements in the host rocks are almost similar to those of the unaltered rhyolitic rocks in the upper horizon.
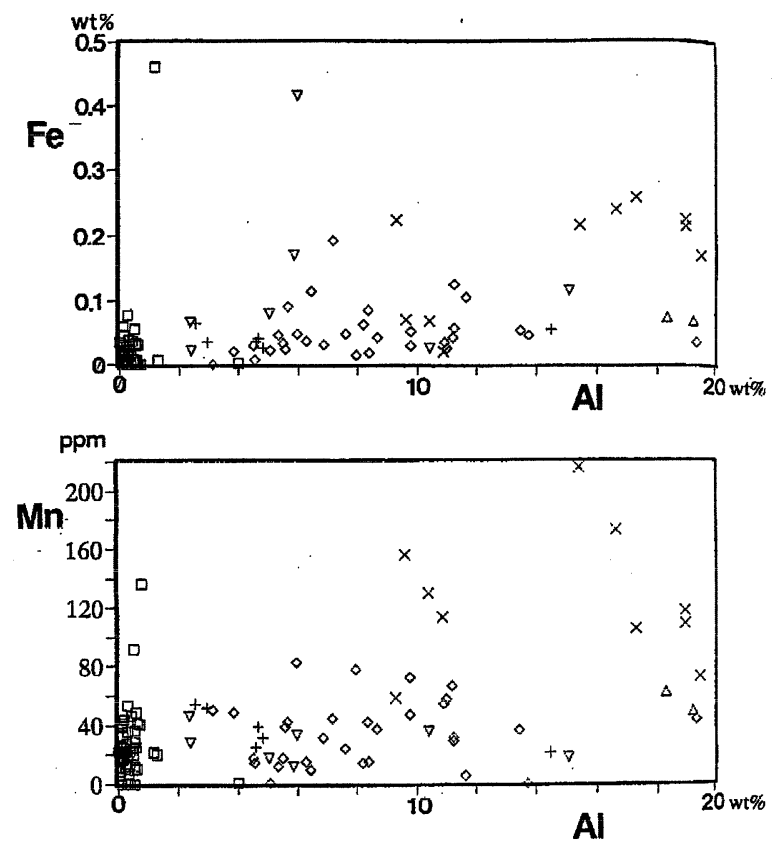

Figurc 9. Variation of $\mathrm{Fe}$ and $\mathrm{Mn}$ contents against $\mathrm{Al}$ content. Silicified rock $(\square)$, spotted Toseki $(+)$, illite-rich Roseki( ()$)$, illite rock developed as a narrow zone $(\Delta)$, pyrophyllite-bearing $\operatorname{Roseki}(\nabla)$ and clay $\operatorname{vein}(\mathrm{x})$.

$\mathrm{Fe}$ contents in the altered rocks are clearly lower than that of unaltered rhyolitic rocks, i.e., the upper rhyolitic rocks. Other elements contained in very small amount in the altered rock are $\mathrm{Na}, \mathrm{Mg}, \mathrm{Ca}, \mathrm{Mn}$ and $\mathrm{Zn}$. These elements are supposed to be dissolved from the host 
rhyolitic rocks to the hydrothermal solution during the alteration processes of plagioclase and colored minerals. $\mathrm{Fe}$ and $\mathrm{Mn}$ are relatively more concentrated in clay veins (Fig. 9). Moreover, $\mathrm{Mn}$ is clearly concentrated in clay veins regardless of their $\mathrm{Al}$ contents.

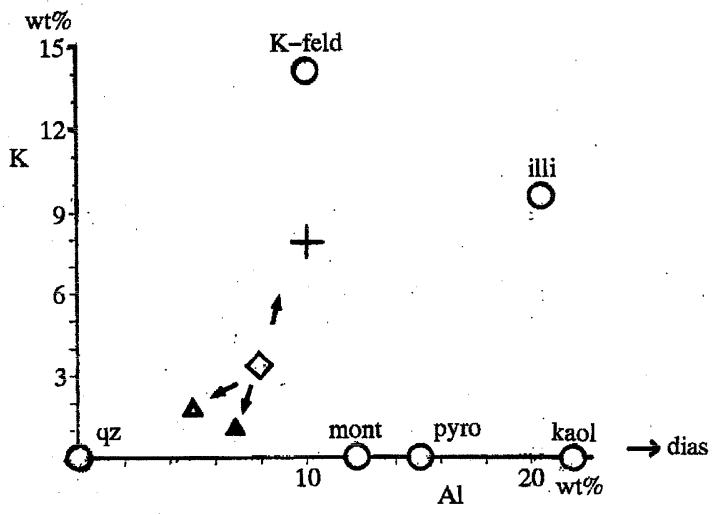

Figure 10. Average value of host rhyolitic rocks $(\diamond)$, average value of the five types of altered rocks and clay vein $(\Delta)$, altered rocks preserving the texture of host rhyolitic rock $(+)$ and average value of pyrophyllite-bearing $\operatorname{Roseki}(\mathbf{\Delta})$ are plotted with main constituent minerals. The altered rocks preserving the texture of host rhyolitic rocks have residual $\mathrm{K}$-feldspar. Ilost rhyolitic rock undergoes a solubilization of silica component. A solidification of silica to the altered rocks such as pyrophyllite-bearing Roseki should be considered.

Average content of $\mathrm{K}$ in the unaltered rhyolitic rock (Fig. 8) is plotted on the diagram showing the compositional variation of rhyolites suffering the alteration conducting the formation of clay deposits and clay vein. The composition of illite rock is also plotted in the figure. In altered rocks, the quantity of illite is, on the whole, much greater than that of pyrophyllite. Average content of $\mathrm{K}$ and $\mathrm{Al}$ in the five types of altered rocks and clay vein (open triangle in Fig. 10) is rather low compared with that of the unaltered rhyolitic rocks (open lozenge). This indicates the addition of silica to the altered rocks (silicification). On the other hand, average contents of $\mathrm{K}$ and $\mathrm{Al}$ in the altered rocks in lower horizon preserving the texture of host rhyolitic rock are higher than those in the unaltered rhyolitic rock in upper horizon. Such tendency can be explained by unaffected K-feldspar. In Figure 10, K-feldspar is plotted at $9.7 \mathrm{wt} \%$ in $\mathrm{Al}$ and $14.1 \mathrm{wt} \%$ in $\mathrm{K}$ considering the chemical composition. The altered rhyolitic rocks preserving the texture of host rhyolitic rock contain a huge amounts of K-feldspar. K-feldspar can withstand hydrothermal alteration for considerably longer times than the other minerals except quartz. From Figure 10, it is strongly suggested that the alteration of the district is the products of leaching and/or dissolution of the host rhyolitic rocks occurred by activities related to the hydrothermal solution. The solubilization of silica component from the host rock and the solidification of silica in the altered rocks should be considered.

\section{Acknowledgement}

The authors are grateful to the late Prof. Sueno for the introduction of LAM-ICP-MS and his discussion and encouragement. The authors would like to present our deepest condolences to his death. Sincere thanks are due to Dr. Miyawaki, Dr Kano and Prof. Aikawa for their useful information and critical reading of the manuscript. This study was partly supported by a Grant-in-Aid for Scientific Research from Ministry of Education in Japan.

\section{References}

Bambauer, H.U. (1961) Spurenelementgehalte und $\gamma$-Farbzentren in Quarzen aus Zerrklueften der Schweizer Alpen. Schweiz. Mineralogische und Petrographishe Mitteilungen, 41, 335-369.

Hervig, R.L. and Peacock, S.M. (1989) Implications of trace element zoning in deformed quartz from the Santa Catalina mylonite zone. The Journal of Geology, 89, 343-350.

Hida, T., Ishiyama, D., Mizuta, T. and Ishikawa, Y. (1996) Geological characteristics and formation environments of the Yano-Shokozan pyrophyllite deposit, Hiroshima prefecture, Japan. Journal of the Clay Science Society of Japan, 36, 62-72 (in Japanese with English abstract).

Hongu, H. and Kohno, T. (1990) A geochemical and mineralogical study of the Roseki deposit of the Tsuchihashi Mine, Okayama Prefecture. Bulletin of Kyushu Sangyo University 27, 313-334 (in Japanese with English abstract).

Hongu, H., Kitagawa, R. and Nishido, H. (2000) Modes of Occurrence and $\mathrm{K}-\Lambda \mathrm{r} \Lambda \mathrm{ges}$ of "Roseki" deposits in Mitsuishi district, Okayama Prefecture. Nendokagaku, 40, 46-53 (in Japanese with English abstract).

Ikeya, T. (1993) New applications of electron spin resonance. World Scientific, Singapore.

Kamitani, M. (1974) Hydrothermal alteration at the Uku Roseki mine, Yamaguchi Prefecture. Mining Geology, 24, 31-43 (in Japanese with English abstract).

Kamitani, M. and Fujii, N. (1972) Study on the Roseki deposits in Mitsuishi area, Okayama Prefecture, west Japan. Bulletin of the Geologycal Survay of Japan, 23, 71-84 (in Japanese with English abstract).

Kano, S. and Matsui, F.Z. (1987) Trace clements and thcir address in Brazilian lasca. Journal of Mineralogy, Petrology and Economic Geology, 82, 299-305 (in Japanese with English abstract).

Kano, S. and Shinohara, A.H. (1989) Origin of trace elements in the Brazilian quartz. 1989 Annual Meeting Abstract, Mineralogical Society of Japan, 101 (in Japanese)

Katayama, N. (1969) Mechanism of mineralization and prospecting principle of Roseki ore deposits. Mining Geology, 19, 31-42 (in Japancsc with English abstract).

Kinosaki, Y. (1963) The pyrophyllite deposits in the Chugoku province, west Japan. Geological Report of Hiroshima University, 12, 1-35 (in Japanese with English abstract). 
Kinosaki, Y. (1965) The mineral paragenesis of the pyrophyllite deposits. Geological Report of Hiroshima University, 14, 173-183 (in Japanese with English abstract).

Kurosawa, M., Jackson, S.F. and Sueno, S. (2001) Trace element analysis of NIST SRM 614 and 616 glass reference matcrials by laser ablation microprobe-inductively coupled plasma-mass spectrometry (LAM-ICP-MS). Geostandards Newsletter, 25, in press.

Mason, B. (1966) Principles of geochemistry. John Wiley. London.

Masuda, F. (1996) personal communication.

Matsumoto, K. (1968) On the geology and pyrophyllite deposits of the Yano-shokozan mine, Hiroshima Prefecture. Geological Report of Hiroshima University, 16, 1-25 (in Japanese with English abstract).

Mitsuno, T. Omori, N., Socda, A., Tsushima, S., Higashimoto. S. and Matsumoto, K. (1984) Geological map of the Itaya-Mitsuishi district. Rept. of Roseki deposits of Mitsuishi-Yoshinaga district, Okayama Prefecture.

Ono, A.(1979) Quartz solid solution in the system $\mathrm{Li}_{2} \mathrm{O}-\mathrm{Al}_{2} \mathrm{O}_{3}-\mathrm{SiO}_{2}-\mathrm{H}_{2} \mathrm{O}$. The Journal of the Japanese Association of Mineralogists, Petrologists and Economic Geologists, 74, 417-420 (Japanese with English abstract).

Pcrny, B. Ebcrhardt, P. Ramscycr, K. Mullis, J. and Pankrath, R.(1992)
Microdistribution of $\mathrm{Al}, \mathrm{Li}$, and $\mathrm{Na}$ in a quartz: possible causes and correlation with short-lived cathodoluminescence. American Mineralogist, 77, 534-544.

Stuner, I.J. and I eininger, R.. (1972) Comparison of the trace element content of plutonic, volcanic and metamorphic quartz from south west Montana, Geological Society of America Bulletin, 83, 1855-1862.

Smith, J.V. and Steele, I.M. (1984) Chemical substitution in silica polymorphs. Neues Jahrbuch für Mineralogie. Monatschefte, 3, 137-144.

lakagi, 'I., Koh, S.M., Kim. M.Y., Naito, K. and Sudo, S. (2000) Geology and hydrothermal alteration of the Milyang pyrophyllite deposit, Southeast Korea. Resource Geology, 50, 243-256.

Terakado, Y. and Fujitani, T. (1998) Behavior of the rare earth clements and other tracc clements during interactions between acidic hydrothermal solutions and silicic volcanic rocks, southwestern Japan. Geochimica et Cosmochimica Acta, 62, 1903-1917

Manuscript received; 17 December, 2001

Manuscript accepted; 23 April, 2002 